\title{
Distribution of heritage To People Which made lost (mafqud) According to Islamic Law
}

\author{
Anindita Atibhakti Ardhani ${ }^{1 *}$ \\ Magister Kenotariatan, Universitas Surabaya,Surabaya,Indonesia \\ *e-mail: "Ianinardhani@gmail.com
}

\begin{abstract}
The purpose of this study is to understand the division of inheritance against people who are declared missing (mafqud) according to Islamic law. The problems examined in this study concerning legal certainty for heirs who were declared missing (mafqud) in the right to inherit and distribution of inheritance after the person declared missing (mafqud) is known to exist. The research method used is normative legal research. The results of the study are the heirs who lost (mafqud) still have rights, be they rights to property or inheritance. This right remains attached as it is when it is still in normal life. When the heirs leave the residence for a considerable time, then their status becomes a lost person (mafqud), then their life status is still recognized. The mafqud heirs mentioned above are part of the heirs due to blood relations (caused by birth) based on the An-Nisa surah, especially verses 7 and 8 . Furthermore, the inheritance case for the mafqud heirs whose existence is known, can still obtain the inheritance part even though the portion has been spent by other heirs, because in fact the heirs who were declared missing or the mafqud may have a substitute heir who will replace the position of the heirs declared mafqud when the inheritance is distributed to the heirs as stipulated in Article 185 verses (1) and (2) KHI.
\end{abstract}

Keywords - Inheritance; Lost;Mafqud.

\section{INTRODUCTION}

Inheritance law, in Arabic terms that is furudh or faraidh is a form of jama 'from the word fariidhah. The word fariidhah is taken from the word fardh which means destiny or provision. So, Faraidh is the provision of the portion received by the heir in the form of a definite amount. Each number/fraction referred to in the Qur'an is something that is certain and does not require further interpretation. [1]. In terms of language, Islamic inheritance law is a provision that regulates people who are entitled to be heirs, people who cannot be heirs (because of being hindered), the number of shares received by each heir and how to distribute the inheritance to heirs. Inheritance law according to Article 171 Letter a Compilation of Islamic Law is "the law governing the transfer of ownership rights to the inheritance (tirkah) of the heir, determines who has the right to be an heir and how many parts are each" [2].

In this connection, it can be said that the Islamic inheritance law is a law that regulates everything related to the transfer of rights and/or obligations on the property after a person dies to the heirs [3]. 
Regulations concerning Islamic inheritance law are outlined in Law Number 7 of 1989 concerning the Religious Courts, which were amendedtwice, namely by Law Number 3 of 2006 concerning Amendments to Law Number 7 of 1989 concerning the Religious Courts and Laws. Number 50 of 2009 concerning the Second Amendment to Law Number 7 of 1989 concerning Religious Courts (hereinafter referred to as the Religious Courts Law) and regulated in Presidential Instruction No. 1 of 1991 (hereinafter referred to as Compilation of Islamic Law).

The law of inheritance in Islamic law occupies a very important place. The Qur'an clearly regulates inheritance law to prevent the accumulation of wealth in small groups of humans, eliminates the gap between classes of society, maximally helps the distribution of wealth regarding the number of offspring, extends the distribution of utilization that wealth and every Muslim also has the right to inherit his wealth to be used to help the poor or benevolent programs that benefit back to the community. As mentioned in the Qur'an, the Surah An-Nisa verses 11-12, which stipulates and ascertains who has the right to be an heir, how many parts are each and when the deceased of the great can be distributed, all are determined and is completely divided in these two verses. However, before the inheritance is divided, it must first be disbursed by the rights of others such as the costs of handling corpses, almsgiving on inheritance and debts of the heir before he dies. After these things are done then the inheritance can be shared between the entitled heirs.

According to Amir Syarifudin, one of the problems relating to inheritance can be found in the absence of certainty about the heirs, even though the heir's right has been determined by his faraidh. That uncertainty can arise because the time of the death of the heir has not been born or lost without the news. These problems can arise due to the absence of instructions from the Prophet, while those that exist are only individual ijtihad from friends between each other different from one another and each has no authority over the other and towards the people who come afterward.

Inheritance distribution can occur and can be implemented if there is an inheritor. According to Article 171 Letter b Compilation of Islamic Law, an heir is "a person who at the time of his death or who was declared dead based on a Muslim court decision, leaving an heir and inheritance". However, the problem then, if there is one of the heirs whose whereabouts are unknown, this results in the delay in the process of distributing the inheritance, until the court determines the certainty of the existence of the heirs, without a court determination, the distribution of inheritance must be suspended first. Regarding the determination of the disappearance of people is still causing debate 
among scholars about the right time to ensure the existence of the disappearance of people or heirs.

Determination of mafqud for lost people is very important because to know the position of mafqud in obtaining rights and obligations in inheritance, which involves two things, first in position as heir related to the transfer of inheritance to him legally, second in position as heir with transition his wealth to the heirs.

\section{METHOD}

This type of research used is the type of Normative Law research or library research is research that studies the study of documents, which uses various secondary data such as legislation, court decisions, legal theory, and can be in the form of the opinions of scholars. This type of normative research uses qualitative analysis, namely by explaining existing data with words or statements rather than numbers and developing the power of interpretation to answer the legal issues discussed in this thesis.

\section{RESULTS}

\section{A. Legal satisfaction for passionary expertslost (mafqud) in the right to heritage.}

Inheritance law is one part of civil law as a whole and is the smallest part of family law. The law of inheritance is very closely related to the scope of human life because every human being will surely experience a legal event called death. The legal consequences which subsequently arise, with the occurrence of the legal event of someone's death, among them is the problem of how the management and continuation of the rights and obligations of someone who died A person's death is considered as the cause of the validity of a person's inheritance law if he leaves a number of assets and has an heir. [4].

The distribution of inheritance in Islam is a necessity (infaqijbari). Determination and distribution of inheritance have been listed in the Qur'an may not be rejected by the heirs who are entitled to receive it, before the distribution of inheritance, after the distribution of inheritance according to the Qur'an / Al-Hadith, and heirs know clearly the part each inheritance, only then has the right to give it to others, the heirs can agree to make peace in the distribution of inheritance after each is aware of its share .

According to Islamic law, inheritance problems will occur if the inheritance requirements are fulfilled. In Article 171 compilation of Islamic Law b, as for the inheritance requirements, there are 3 (three), namely:

1. Death of his Muwarrits (Heir).

2. Life of Warits (Heirs).

3. Knowing the status of Inheritance.

Regarding the legal status of missing persons (mafqud), Islamic jurists determined that: .

1. The wife of a missing person cannot be married.

2. The assets of missing persons cannot be inherited. 
3. The rights of missing persons may not be spent or transferred.

The inclusion of the three things mentioned above until the missing person is known by their status, namely whether they are still alive or have died. And if it is still in doubt, its status must be considered as still alive according to the original conditions. And it can be added, that the only person entitled to determine someone who disappeared is dead is the Judge [5].

The purpose of determining the heirs who are declared missing (mafqud) through the Religious Courts is to obtain legal certainty, legal legality, and legal documents. Judges in making decisions to determine the legal status of Mafqud must be based on valid legal sources for the realization of a court that has legal certainty.

Distribution of inheritance must also be carried out immediately to avoid the emergence of mudhorot, such as damage to assets, increasingly complex calculations, even damage to family relations. What needs to be emphasized is to build awareness for all heirs, that sharing this inheritance is an obligation that God has sent down upon His servants. All must abide by these provisions and act calm no matter what the outcome. This initial attitude will launch the next stages of the division of assets.

Allah SWT starts the inheritance verse in Surah An-Nis' with His word:

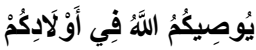

Meaning: "Allah prescribed to you about (the distribution of heirlooms to) your children". [6].

The limitations of laws and regulations that regulate inheritance mafqud cases specifically in the absolute competencies of the Religious Courts raise problems and cause the Judge to strive harder in establishing the legal basis for their decisions and decisions. It can be said that the laws and regulations regarding the case of mafqud are not completely clear or even incomplete. It's just that these limitations are assisted by General Explanations points 2, 3 and 4 of the Compilation of Islamic Law which allows Judges to refer to the doctrine of jurists or fiqh scholars.

Two considerations can be used by Judges in determining the clarity of the legal status of death from mafqud. Such legal considerations and remedies are not legally strong enough, but some are acceptable and have legal references.

1. Based on authentic evidence that can be justified syara'.

As a basis for determining the death of mafqud. As in the rules of ushulfiqh: [7].

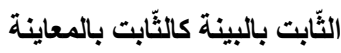

Meaning: What remains based on evidence is like what remains based on reality.

So, for example, there are people who are fair and trustworthy to give testimony that the missing person (mafqud) has died, then the judge can make the basis of the testimony to determine the status of mafqud's death. He 
was appointed as a person who had died haqiqy since it was decided by the judge.

2. Based on the time limit for the departure of Mafqud.

In the book MughniMuhtaj it is stated:

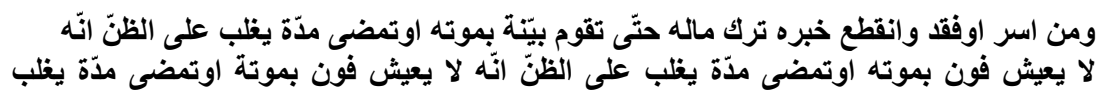

Meaning: "A person who is detained or someone who breaks the news and leaves the property will be delayed (not shared) until there is clarity about his death or for a long time so that it is estimated to be dead and the judge has decided that the mafqud is dead then the property is given to the expert inheritance at the time the law occurs.

Determination of mafqud for lost people is very important, because to know the position of mafqud in obtaining rights and obligations in inheritance that is related to two things, first in position as heir in relation to the transfer of property to heirs, the second in position as heir related to transition heir's assets to him legally.

The determination of mafqud for lost heirs does not just invalidate the right to inherit it. As for the ways of resolving the inheritance of the missing person, it should be done first some parts of each of them if the missing person is considered to be still alive, then again how many parts of each of them if the missing person is considered dead and then from the two estimates, the heirs are given the smallest part of the two estimates. The rest was held for the missing person.

B. Distribution of heritage treasure after the peoplerevealed (mafqud) known the existence.

It is important to know the importance of systematic completion in dealing with inheritance issues related to Islamic inheritance law. In other words, some stagesmust be passed and if these stages are passed correctly, then no matter how complicated the inheritance problem faced, this complexity can easily be solved. These stages are important to go through, in addition to facilitating the settlement of inheritance cases, as well as to anticipate mistakes early. The following are the steps that must be passed. [5].

1. Determine Heirs.

2. Hijab / Obstacle-Blocking Problems.

3. Determine Ashabah.

4. Determine the portion / FurudhulMuqaddarah.

Heirs according to Article 171 Letter c Compilation of Islamic Law is "a person who at the time of death has a blood relationship or marital relationship with the testator, is Muslim and is not hindered because of the law to become an heir".

The heirs determined by their parts in the Qur'an are only heirs of 
dzulfaraa'idh so that their parts are forever certain and unchanging, in contrast to other heirs who are not dzulfaraa'idh namely ashabah and dzularhaam, part they are the remainder after the rights of the heirs of dzulfaraa'idh are issued. The permanent portion of the heirs of DhulFaraa'idh is detailed in the following, namely: (EmanSuparman, 1995: 17-18).

Errors in determining the heirs can be fatal because the inheritance rights can be received by people who are not entitled to inheritance. This early error will lead to errors that are successive in the later stages.

Compilation of Islamic Law, especially in the provisions contained in Book II Chapter I article 171 letter estates, inheritance is "inherited property plus part of joint assets after being used for the needs of the testator during illness until death, the cost of arranging the corpse (tajhiz), payment of debt and gift for relatives ". The following 4 (four) things that must be considered (removed from the inheritance) before being distributed, namely [5]:

a. Costs of Heir Care.

b. Heir Grant.

c. Will's Will.

d. Debt inheritance.

The person who is missing or mafqud according to syara 'is a person who leaves (there is no place) that is unknown to his place and does not know whether he is still alive or has died..

The distribution of various types of mafqud is only certain in the opinion of the Ulama, in this case, the opinion of the Ulema of the Malikiyyah and Hanabilah circles. Malikiyyah divides mafqud into 4 types :

1. Lost in an Islamic country. In this case, the wife is allowed to sue for divorce from her husband.

2. Lost in the land of the enemy (infidel). The law is the same as the law of a prisoner, meaning that his wife cannot be married and her property cannot be shared. Except for the opinion of Asyhab, which says that the law of the husband is the same as the law of the missing person in an Islamic country.

3. Lost in the Islamic war, namely the war between Muslims. Malik argues that missing people are equated with people who are killed without having to wait. Another opinion said that it must be awaited based on the proximity or distance where the war occurred. But for Malik, the longest waiting period is one year.

4. Lost in battle with the infidels. About this matter, there are four opinions. First, the law is the same as the law of the person being taken, prisoner. Second, the law is the same as the law of the person killed after waiting for one year, unless he is in a clear place, then it is equated with the law of people who are lost in war and acts of violence that occur between 
Muslims. Third, the law is the same as the law of the lost in the land of the Muslims. Fourth, the law is the same as the law of the person who is killed about his wife, and the same as the law of the person who is lost in the land of the Muslims regarding his property. That is to wait, then share it.

While the Ulama of the Hanbali school divided mafqud into 2 types, namely:

1. Disappearances that according to birth are safe, such as going to a trade to a place that is not dangerous, going to study and wandering.

2. Lost which according to birth did not survive, such as a person who suddenly disappeared between his family, or went out to pray but did not return, or left because of a necessity that should return, then there was no news or lost between two fighting forces or at the same time as a ship sinking and so on.

The problem that arises against the person who is Mafqud is his inheritance, both his position as heir and as heir. (SyamsulbahriSalihima, 2015: 98). To elaborate further, it is necessary to differentiate separation in their functions:

1. As a muwarrits, people who inherit their inheritance to the heirs.

2. As a warits, the person who inherits the inheritance's inheritance.

According to Amir Syarifuddin, a person can inherit inheritance because of 4 (four) things, namely: (Ahmad AzharBasyir, 1987: 15).

1. Relationship of blood or blood, such as father, mother, child, grandchildren, siblings, family, a thousand and so on.

2. Marriage relations, namely husband or wife, even though they have never been gathered or divorced, but are still in the 'iddahraj'i divorce period.

3. The relationship of wala ', that is the relationship between the former slave and the person who freed him, if the former slave did not have an heir.

4. Relations between Muslims, what is meant here happens if someone who dies does not have an heir, then the inheritance is handed over to the public treasury or called BaitulMaal which will be used by Muslims. Thus, the property of Muslims who do not have an heir is inherited by Muslims.

For someone does not inherit (loss of inheritance/barrier to damage) because of the following:

1. An obstacle to inherit.

Inheritance obstacles are actions or things that can invalidate a person's right to inherit because of inherited causes or conditions. However, because of something they cannot accept inheritance rights. (Fathurrahman, 1975: 83). Because someone does not inherit mentioned in the provisions of Article 173 Compilation of Islamic Law:

A person is deterred from being an heir if the decision of a judge who has permanent legal force is punished for: 
a. blamed for killing or trying to kill or persecute the heirs severely;

b. blamed slanderously filed a complaint that the heir had committed a crime which was punishable by a sentence of 5 years imprisonment or a more severe sentence.

2. The virtue group, Hijab, and Mahjub.

As with other inheritance laws, Islamic inheritance law also recognizes the grouping of heirs to several groups of virtues, for example, children are more important than grandchildren, fathers are closer (more important) to children than siblings, fathers are closer (more important) to the child compared to grandfather. This group of virtues can also be caused by the strong kinship relationship, for example, siblings are more important than siblings or a thousand because siblings have two connecting lines (ie father or mother only) [5].

The details of the heirs have been largely explained by Allah SWT in the Qur'an or through the explanation of the prophet in the hadith as well as that which is understood through the expansion of the understanding of the heirs contained in the Qur'an. For this reason, the following are the heirs who are entitled to receive the inheritance [5].

1. Heirs in the Blood / Nasab Relationship.

A blood relationship that causes an inheritance relationship is a blood relationship or nasab relationship between the person who inherits it and the person who inherits it caused by birth. Blood relation is the strongest inherent cause because blood relation is an element of causality for someone who cannot be eliminated.

Viewed in terms of lines connecting between inheritance and inheritance, blood relations can be classified into three.

a. Furu '(Descendants / Branches of the testator).

b. Usul (Principal / Origin).

c. Hawasyi (Family Line Sideways).

2. Heirs in Marriage Relations.

Marriage is a social bond or bond of a legal agreement between individuals that forms kinship relationships and which is an institution in the local culture that formalizes interpersonal relationships that are usually intimate and sexual.

Compilation of Islamic Law, especially in the provisions contained in Book II Chapter II article 2, states "Marriage according to Islamic law is marriage, which is a very strong contract or miitsaaqanghaliizhan to obey Allah's orders and do so is worship".

Heirs caused by marital relations are husband or wife, where the husband becomes the heir to the wife and vice versa the wife is the heir to the 
husband. The position of husband or wife as heirs is explained by God in the surah An-Nisa 'verse 12.

The existence of a marriage relationship between a man and a woman does not cause any inheritance rights to the relatives of the wife or relatives of the husband. In this case the stepson of the husband is not the heir of the husband, likewise, the stepchild of the wife is not the heir of the wife. In this case, there is no difference among the scholars of Fiqh.

The loss of heirs (mafqud) can be replaced by a substitute heir. The theory of substitute heirs, in the provisions of Article 185 Compilation of Islamic Law consists of two verses, namely:

1. Heirs who died earlier than heirs, their position can be replaced by their children, except those mentioned in Article 173.

2. The substitute heirs may not exceed the equal heirs of the heirs replaced.

The concept of substitute heirs in the Compilation of Islamic Law cannot be separated from the opinion of Prof. Hazairin. Therefore, the legal basis for a successor is stated in the Qur'an surah An-Nisa verse. This verse according to Hazairin is a blessing as much as possible for humanity, if there is no such grace, then what else is the legal basis that can be channeled from the Qur'an to establish inheritance rights for others aqrabun (close heirs) which are not in the verses of inheritance in the Qur'an such as uncles and aunts, grandparents, grandchildren and grandchildren and so on. Which can then be formulated as follows:

1. Those who are substitute heirs are all descendants, heirs who die before the heirs.

2. The number of parts received by substitute heirs may not exceed (equal maximum) of the part that should be replaced. This is in line with the opinion of Hazairin that in the matter of the virtues formulated in the Qur'an it is stated that the position of father and child and descendants must be prioritized.

3. Position of grandchildren, both male and female descendants are equally entitled to replace the position of the father.

For the sake of fulfilling dharuriyat needs (basic needs) that exist in every human being, fellow Muslims must be obliged to help in terms of sustaining life, however small the form of help, is very very noble in the eyes of Allah SWT. If these needs are not met, the safety of humanity will be threatened both in the world and in the hereafter. Dharuriyat's needs include:

1. Maintaining Religion (Din).

2. Keeping the Soul (Hifzhun-Nafsi).

3. Keeping Intellect (Hifzhul-Aqli).

4. Maintaining Descendants (Hifzhun-Nasli).

5. Maintain Property (Malls).

Keeping what is in the five basic needs (dharuriyâtul-khamsa) in human 
beings cannot be separated from inheritance to maintain the sustainability of a human's life. But in the case of inheritance in which the heirs have long been lost (mafqud) then appear alive, after the verdict from the judge about his death and inheritance has been distributed to the other heirs, to the part detained for mafqud though. The previous statement was strengthened by the school of Imam Shafi'i, where if the mafqud was an heir, his wealth was postponed until the situation was clear, while the rest of the heirs could be given immediately. Then, when the heirs of the mafqud or the heirs of the substitute appear to be alive, then the right to take the remaining portion that remains in the hands of the heirs. This means that if the portion that has been distributed to the heirs has been used up or has been damaged so that there is not the slightest remainder, the heirs can be held accountable for replacing or exchanging. The judge's decision regarding the death of the heirs of the mafqud is only as a reference so that the inheritance is immediately distributed to other heirs to avoid harm. Then, the five basic needs (dharuriyâtul-khamsa) become the basis for maintaining the familial relationship between the lost heir (mafqud) with his family, then some of the assets owned by his family can be inherited by his family to the heir who is missing the expert or heir to the substitute earlier by way of make a grant.

\section{IV.DISCUSSION}

a. Lost heirs (mafqud) still have rights, be they rights to property or part of the inheritance. This right remains attached as it is when it is still in normal life. When the heirs leave the residence for a considerable time, then their status becomes a lost person (mafqud), then their life status is still recognized. The heirs of the mafqud mentioned above are part of the heirs due to blood relations (caused by birth) which are based in Surah An-Nisa, especially verses 7 and 8 .

b. The case of inheritance on the heirs of Mafqud whose existence is known, can still obtain part of the inheritance even though the part has been spent by other heirs, because actually the heirs who are declared missing or the mafqud may have a substitute heir who will replace the position of the heirs declared Mafqud when the inheritance is distributed to the heirs as stipulated in Article 185 paragraph (1) and (2) KHI.

\section{CONCLUSION}

Related to the case of lost heirs (mafqud) cannot be considered trivial. The compilation of Islamic Law used as a reference in solving inheritance cases is still lacking in the response of lost heirs (mafqud) or the status of the lost heirs (mafqud). So, it is better to make improvements regarding the heirs that are declared lost (mafqud), because the distribution of inheritance based on Islamic law aims to provide protection and preserve the benefit of humans, especially Muslims. Five necessities (dharuriyâtul-khamsa) form the 
basis for maintaining family relations and friendship between lost heirs (mafqud) and their families, so some of their possessions can be inherited by their families to the missing heirs or heirs by making grants.

\section{REFERENCES}

[1] Syarifuddin, A. (2004). Hukum Kewarisan Islam. Kencana

[2] Rachmadi, U. (2009). Hukum Kewarisan Islam.

[3] Ali, M. D. (2007). Hukum Islam, PengantarIlmuHukumdan Tata Hukum di Indonesia.

[4] Sarmadi, A. S. (1997). Transendensi Keadilan Hukum Waris Islam Transformatif. Raja Grafindo Persada.

[5] Lubis, S. K., \& Simanjuntak, K. (1995). Hukum waris Islam:(lengkap dan praktis). Sinar Grafika.

[6] Departemen Agama, Mushaf Al-Qur'an Terjemahan, 2002, AlHuda,Depok.

[7] Yahya, M., \& Rahman, F. (1979). Dasar-dasarpembinaanhukumfiqhIslamy. Sa'adiyah Putra. 